
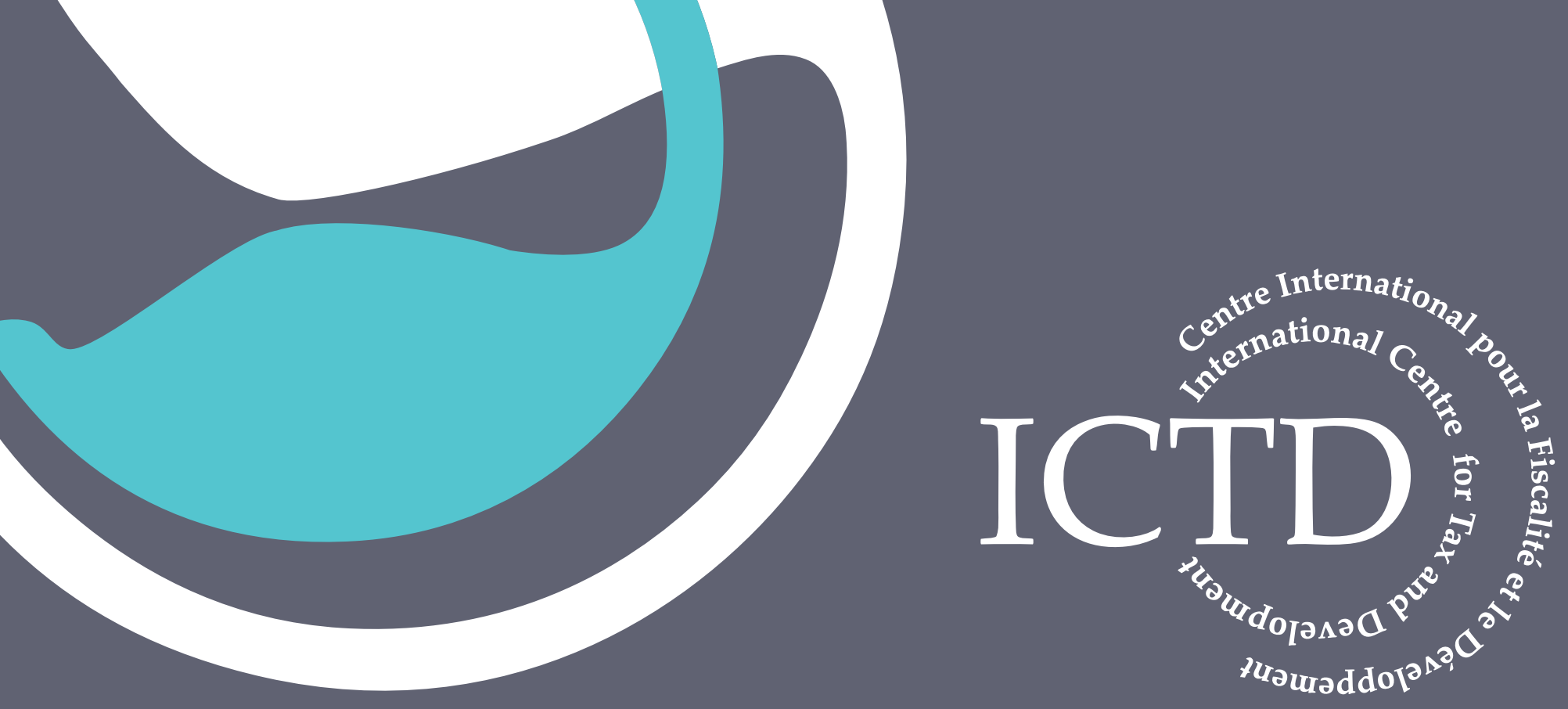

Working Paper 33

\title{
Understanding Irow-Irevel State Capacity: Property Tax Collection in Pakistan
}

Mujtaba Piracha and Mick Moore

March 2015 


\section{ICTD Working Paper 33}

\section{Understanding Low-Level State Capacity: Property Tax Collection in Pakistan}

Mujtaba Piracha and Mick Moore

March 2015 
Understanding Low-Level State Capacity: Property Tax Collection in Pakistan Mujtaba Piracha and Mick Moore

ICTD Working Paper 33

First published by the Institute of Development Studies in March 2015

(C) Institute of Development Studies 2015

ISBN: 978-1-78118-226-0

A catalogue record for this publication is available from the British Library.

All rights reserved. Reproduction, copy, transmission, or translation of any part of this publication may

be made only under the following conditions:

- with the prior permission of the publisher; or

- with a licence from the Copyright Licensing Agency Ltd., 90 Tottenham Court Road, London W1P 9HE, UK,

or from another national licensing agency; or

- under the terms set out below.

This publication is copyright, but may be reproduced by any method without fee for teaching or nonprofit purposes, but not for resale. Formal permission is required for all such uses, but normally will be granted immediately. For copying in any other circumstances, or for reuse in other publications, or for translation or adaptation, prior written permission must be obtained from the publisher and a fee may be payable.

Available from:

The International Centre for Tax and Development

at the Institute of Development Studies

Brighton BN1 9RE, UK

Tel: +44 (0) 1273606261 Fax: +44 (0) 1273621202

E-mail: info@ictd.ac.uk

Web: www.ictd/en/publications

IDS is a charitable company limited by guarantee and registered in England (No. 877338) 


\title{
Understanding Low-Level State Capacity: Property Tax Collection in Pakistan $^{1}$
}

\author{
Mujtaba Piracha and Mick Moore
}

\section{Summary}

This paper is based on a detailed analysis of how field staff in the Excise and Taxation Department of the Punjab Provincial Government collect the (very low-yielding) property tax. In general, informal practices and relationships play a major role. More specifically, field staff enjoy considerable discretion in making key decisions about property tax assessment; the additional earnings that they are able to get from colluding with taxpayers are used in part to employ support staff and cover routine operating costs; and field-level staff are deeply rooted in the locality where they work, typically serving in one office for their entire career, and both monopolise and manipulate the information on the tax base and on collection performance that senior management would need to establish effective control of the system. In contrast more senior staff are transferred frequently between postings and have short time horizons in any particular posting, and senior staff have little capacity either to monitor and assess the performance of junior staff or to discipline them. It would, however, be misleading to attribute the poor performance of the property tax system principally to the behaviour of tax collection staff. There is considerable evidence that the low-level equilibrium that we observe stems in large part from the relative lack of interest of various levels of government in property tax revenue, and the priority they give to keeping the levels of government below them dependent or disempowered. There is potential to improve the property tax system, especially through wider use of information technology. Should there be adequate political support for reform outside the Excise and Taxation Department, implementation would be very difficult without taking account of the capacity of field staff to block change, and of the need to negotiate change with them.

Keywords: property tax; tax administration; Pakistan; Punjab; corruption; informality; information asymmetry.

Mujtaba Piracha is a Doctoral Candidate at the Institute of Development Studies, University of Sussex, UK. He is a senior officer in the Pakistan Administrative Service.

Mick Moore is a Professorial Fellow at the Institute of Development Studies and the founding Chief Executive Officer of the International Centre for Tax and Development, UK.

We are grateful to Ali Cheema and Shandana Khan Mohmand for extremely helpful comments on an earlier draft. 


\section{Contents}

Summary $\quad 3$

Introduction $\quad 5$

$\begin{array}{lll}1 & \text { Introducing property tax administration } & 7\end{array}$

2 Field-level administration: an office encounter 9

$3 \quad$ Field-level administration: the underlying system 10

4 Supervisors' dilemmas: an office meeting 13

$5 \quad$ Supervisors' dilemmas: information asymmetry 14

$\begin{array}{lll}6 & \text { Arrears } & 15\end{array}$

$\begin{array}{lll}7 & \text { Arrears: the strategic use of information } & 16\end{array}$

$8 \quad$ Campaigning for collection 16

$\begin{array}{llr}9 & \text { Concluding comments } & 18\end{array}$

$\begin{array}{ll}\text { References } & 20\end{array}$ 


\section{Introduction}

Taxation is contentious. Tax-paying is compulsory, but implies no specific entitlement to any reciprocal service. Formally payment obligations are established by law and tax code, and are supposed to be determined by objective, quantifiable factors such as income, business turnover, size of property, value of assets, import volumes, line of business, employment status, profit level, or motor vehicle engine capacity. But many of these volumes or values are subject to conflicting interpretation, and the people who actually assess and collect taxes face a continuous temptation to collude with taxpayers to agree an assessment that is less than the legal level, and share the difference between them to the detriment of the public exchequer. Consequently certain themes recur in the history of taxation: higher-level state authorities struggle to control their tax-collecting personnel; aggrieved taxpayers revolt; and tax collection, like policing, becomes a major channel for state-licensed rent-taking. Even where tax collection has been organised through formal public bureaucracies, the actual relationship between the central state, collectors and taxpayers has often been akin to tax farming: collectors are permitted wide scope to gather what they can, provided they deliver an acceptable level of revenue to the public treasury (Adams 1998; Awasthi and Bayraktar 2014; Bräutigam 2008; Butcher and Dick 1993; Daunton 2001; Gardner 2012; Webber and Wildavsky 1986).

However the incidence of de facto tax farming under the guise of formal bureaucratic tax collection has been shrinking steadily at the global level. One of the less-appreciated organisational innovations of the modern world is a set of technologies that in large degree automate processes of tax assessment and collection, making them more impersonal and rule-bound, and less corrupt. The most tangible dimension is the replacement of physical verification processes for assessing tax liabilities - i.e. a visit from the tax collector - by accounts-based verification. This is a developmental sequence. At some point in history there were rarely feasible alternatives to physical verification. It is almost inevitably associated with the merging of assessment with collection: the same person who assesses liabilities also collects money from the taxpayer. Physical verification encourages both extortion from and collusion with the taxpayer. Accounts-based verification has its roots mainly in corporate and personal income or profits taxes. It creates three developmental opportunities. One is the employment of revenue agents whose skills lie more in accounting and law rather than muscle power and force. The second is the increased scope for separating the process of assessing liabilities from the process of collecting money, thus reducing the scope for extortion or collusion. The third, which applies in particular to digitalisation, is the enormous potential for improving the effectiveness of assessment by comparing data from different sources.

Accounts-based verification is steadily replacing physical verification throughout the world. It is associated with a number of other practices that reduce the degree of friction and conflict around tax administration. These include: efforts to treat taxpayers more like commercial customers, including measures to make it easier and cheaper for them to comply with tax demands; wider scope for taxpayers to appeal to independent adjudicators in the event of disputes; and the concentration of auditing resources on those categories of taxpayers who are revealed, through statistical analysis of digitalised records, to be at higher risk of noncompliant behaviour. These modern taxation technologies have spread more widely in the collection of internal taxes - corporate and personal income taxes, sales and value-added taxes, excise taxes - than the collection of border taxes. Border taxes, especially import duties, generally account for a higher proportion of government revenue in low-income countries. There, physical verification of imports and exports is still the rule, and in some countries customs duties are one of the largest sources of licensed rent-taking. However even customs rents are under some threat from the spread of preferred trader schemes developed and promoted by the World Customs Organisation in particular: importers and 
exporters with established records of tax compliance can pre-clear their shipments electronically, and largely avoid physical inspection at borders - unless physical inspection is required for security or health reasons (Aberbach and Christensen 2007; Bergman 2003; Bird 2004; Bird and Zolt 2008; Cantens et al. 2010; Kidd 2010; Kloeden 2011; Moore 2014; Vázquez-Caro and Bird 2010; Zake 2011).

Globally, tax bureaucracies increasingly work in a Weberian mode: standard rules and procedures are replacing discretion; personal relationships between individual tax collectors and taxpayers are of declining significance; and professional skills are increasingly required of tax staff. ${ }^{2}$ However, in addition to customs, there is one other sphere of tax collection where physical verification processes still dominate, particularly in low-income countries along with high levels of agent discretion, corruption, collusion and rent-taking. This is the collection of property taxes, especially the recurrent (annual) taxes that owners or occupiers of urban residential and commercial property are obliged to pay to local/subnational governments in most countries in the world. There are a number of reasons for the persistence of these 'backward' practices in the collection of property taxes in low-income countries. They are intimately related to the fact that property tax collection is generally very low, and that there seems to be relatively little to show for the many attempts that have been made, often with the support of aid donors, to reform property tax systems. The reasons include: the general unpopularity of property taxes with the more influential propertied classes, especially because the process of paying property taxes is especially visible and irritating to the taxpayer; property taxes are generally assigned to - and assessed and collected by - relatively weak local or subnational governments that cannot mobilise the organisational and political resources enjoyed by national tax collection agencies; and the fact that digital technologies, including use of remote sensing and digital mapping, which can in principle revolutionise the collection of property taxes, are relatively new and not yet widely used (Bahl et al. 2008; Bird and Slack 2004, 2006; Connolly and Bell 2009; Hale 1985; Jibao and Prichard 2013; McCluskey et al. 2013; National Institute of Urban Affairs 2010; Norregaard 2013; Orton 2005; Phillip and Gary 2003; Rao 2013).

So property tax systems in low-income countries typically raise little revenue. And efforts to reform them have generally disappointed. Pakistan is an extreme case. Although the property tax system is long established, the yield is unusually low. ${ }^{3}$ Reform projects have regularly come and gone. For Pakistan, as for other low-income countries, there is no shortage of reform recommendations. Indeed there is a relatively standard reform menu. It typically includes: update property valuations more regularly and reliably; digitalise property records and shift to electronic billing and payment; enforce discipline on collection staff; simplify valuation schedules so that valuation and collection staff have less scope for discretion; and provide field staff with pecuniary rewards for improved collection performance.

Why do these reform measures have little impact? And what might be the alternative? We address these questions in this paper by reporting the results of an ethnographic and organisational study of the practice of property tax administration at field level in the Punjab, Pakistan's largest province. ${ }^{4}$ The study focused on ways in which field staff do their jobs and

Other contrary (non-Weberian) trends are not discussed here. They include the increasingly frequent movement of staff between tax agencies and the private sector, and the growing extent to which politicians holding government positions negotiate tax deals directly with individual companies to persuade them to invest or relocate their offices and headquarters in the country in question.

3 In 2012/3 the combined revenue from property tax and the main tax on property transfers, the registration fee, amounted to only $0.03 \%$ of GDP <http://www.finance.gov.pk/fiscal/July_June_13.pdf> accessed 12 October 2013. The more typical figure for low-income countries lies within the range of 0.1 to $0.6 \%$ of GDP (IMF 2011; Kelly 2013).

This paper is based on some of the data collected for his doctorate by the first author, Mujtaba Piracha, including interviews with current and retired staff, observation and examination of official departmental files and records. Piracha is a senior officer in the Pakistan Administrative Service. His began the research with a letter of support from the chief secretary to the Punjab Provincial Government, and the approval of the secretary and the director general of the Punjab Excise and Taxation Department. They ensured that other officials in the department understood that his research was 
their relationship with taxpayers, departmental superiors and politicians. What incentives and threats do they face? What resources do they command in managing these relationships? How do they use them? What mix of objectives do they pursue? We show that property tax administration has many characteristics of relatively decentralised tax farming. It is a system - different components interlock and reinforce one another - that is close to equilibrium, at a low level of performance. It generates a continuous stream of modest rents for many of the participants, who have evolved ways of buffering their activities against regular attempts to improve short-term collection performance and sporadic efforts at more structural reform.

We outline the formal structure of the property tax administration in Section 1. We build up an account of ways in which the system operates by alternating between presentations of field research observations (Sections 2, 4, 6 and 8) and analyses of the implications (Sections 3, 5 and 7). We present the implications of the analysis in Section 9.

\section{Introducing property tax administration}

This paper deals with the administration of what is formally termed the Urban Immovable Property Tax. This is an annual tax on the ownership of residential, commercial and industrial property in urban areas, and is known colloquially as property tax. In Pakistan, as in many other countries, property tax is not the only tax levied directly on the ownership or occupation of real estate. Indeed five separate charges are levied on formal transfer of ownership of urban real estate. They are significant to this paper only to the extent that they collectively provide more revenue for subnational governments than does property tax. ${ }^{5}$

Like most of South Asia, Pakistan retains a variant of the colonial British property tax system (rates), in which properties are valued at their estimated rental return - not their capital value. Pakistani governments have radically modified the colonial system in one respect: large discounts are given for owner-occupation of both commercial and residential premises. Currently rented commercial properties are assessed at five times the rate of owneroccupied properties. The differential for residential property is ten times. Most property taxpayers therefore face low assessments. For example, in the cities where we did field research the annual assessment of an owner-occupied house with 500 sq yd of land in the highest value category was only about Rs.5000, or approximately US\$50. In Pakistan, as in many countries, property revaluation is routinely postponed. The property valuation tables currently in use in the Punjab were drawn up in 1999. In the interval actual rental values have increased severalfold.

Responsibility for the administration of property tax is divided among the three main tiers of subnational government: provincial, district and town. The dominant role is played by the provincial level where rates and exemptions are decided, and from where the collection apparatus - the Excise and Taxation Department - is largely controlled. Operational budgets for the department are provided by district authorities, while town authorities control the zoning of areas newly eligible for property tax. ${ }^{6}$ Town authorities are also supposed to

purely for academic purposes. He chose his own field sites and established rapport and credibility with staff at various levels. He spent four months at the primary research site, Region B in Lahore, and a month each in Multan and Rawalpindi tax regions. These three cities are large urban centres in north, central and southern Punjab and have varied recent experience of revenue collection. Once installed in the field offices, he reinforced the message that he was acting only in a research student role. Sharing stories about his own earlier experience as a field-level public servant served as a way of building trust. The fieldwork lasted a year, including six months of office-based observation in the three main research sites, and short visits to three smaller towns: Sahiwal, Khanewal and Murree.

5 These are: stamp duty on transactions; a registration fee for changes in property records; a capital value tax on transfers, recently reallocated to the provincial government from the federal government; a transfer tax on immoveable property; and a withholding income tax on real estate transactions recently introduced by the federal government.

$6 \quad$ The legal situation is complex. Under Punjab Local Government Ordinance 2001 and Punjab Immoveable Property Tax Act 1958 (Amended), the whole of the town jurisdiction is eligible for imposition of property tax at 'zero' tax rate. The 
receive 80 per cent of property tax receipts; the provincial government sometimes diverts some of this money to water and sanitation agencies in large cities that continually run deficits. This division of responsibilities among subnational governments - and the mismatch between responsibility and allocation of revenue - helps explain the relative lack of organisational zeal in collecting property tax (Section 9).

This paper deals with those offices of the Excise and Taxation Department of the Punjab Provincial Government that collect property tax - and not with other offices within the department that collect the more lucrative excise taxes on liquor and motor vehicles. There are four organisational levels within the department. We classify the top two as senior levels. They are the secretary and director general at provincial level, and nine regional directors. These provincial and regional officers have responsibility for all the activities of the department within their jurisdiction, including the collection of excise taxes on liquor and motor vehicles. There are large gaps - in background, career expectations, work culture, knowledge and experience - between them and those staff we label as field-level. The field staff whose work patterns we researched are responsible principally for property tax. ${ }^{7}$

The most senior of the field-level staff are the excise and taxation officers (ETOs), each in charge of a rating area. There are about seventy in Punjab Province. Each ETO is assisted by an assistant ETO. ${ }^{8}$ Each ETO supervises about seven circles. The circle is the lowest unit in the hierarchy. Each circle is headed by a tax inspector, who is primarily responsible for initial assessment of property and updating property records. There is also one constable, who goes from house to house to deliver property tax bills. The bills are paid at banks. The constable is also charged with reporting new information about property that is relevant to assessments. In principle, each circle employs a clerk. However, in 2012 the Punjab Excise and Taxation Department reported that there were official clerks posted only in 268 of the 483 circles in the province. As we explain in Section 3, the circles employ and pay large numbers of unofficial clerks on an informal basis. The staff of each circle typically operate as a relatively cohesive and autonomous entity. They do, however, share the same office buildings as their ETO and the staff of other circles in the rating area.

The various dimensions of the differences in background, experience and expectations between senior (provincial, regional) and field-level (rating area, circle) staff become more evident in the following sections. The primary indicator - and much of the underlying cause lies in the difference in work experience and career orientation. Regional directors are in transferable posts. They expect to move from one location and position to another within Punjab Province. Even if a transfer does not involve a formal promotion, it may involve a move to a more rewarding location (Section 4). By contrast, field-level staff are predominantly localist. They have limited promotion prospects, and are likely to serve their entire careers in the same locality - in the same circle, rating area or city. For most field-level staff stationed outside large cities, a transfer to a different location is an unlikely prospect. ${ }^{9}$ It would be a punishment - one of the few reliable disciplinary procedures to which they are subject (Section 5). As we shall see below, the resulting loss of local knowledge and local

elected town council is authorised to set the rate of any particular area (that does not have a positive rate of tax), obviously newly-urbanised areas. According to the law they can set any rate they want. In practice the town council has to set the rate levied uniformly across the province by the provincial government. So actually town councils have control only over imposition of property tax in a new area, not of setting the tax rate.

Most of them are also obliged to collect other minor levies, including the cotton levy, education duty, hotel tax and professional tax. Property tax is however their dominant revenue source and focus.

In larger districts that are regional headquarters, and where a regional director is based, the primary formal role of an assistant ETO is internal auditor. In smaller districts that are not regional headquarters, there is no internal auditor. The assistant ETO is the assessing authority, and the ETO the appellate authority.

$9 \quad$ There is direct recruitment to the positions of constable, tax inspector and ETO. There is scope for constables to be promoted as far as tax inspectors. Most ETOs are promoted from the ranks of tax inspectors, although a few are recruited directly. 
social and political connections would reduce both their income, and their social standing and influence.

\section{Field-level administration: an office encounter}

In the sixth week of field research, the first author - who appears in this section in the first person - was sitting in the office of an ETO to whom we give the pseudonym Saeen. A middle-aged woman, who we will call Mrs Chalak, walked in. She showed Saeen her recent property tax bill, explaining that it related to a residential house owned by her mother-in-law. Note that the annual tax assessment on the property was likely similar in value to her monthly electricity bill. Mrs Chalak complained that the assessment must be wrong, as the bill never used to be this high. Saeen took the bill and asked Mrs Chalak if her mother-in-law was a widow. Mrs Chalak said that she was. Saeen then picked up his cellphone and called the relevant tax inspector, telling him the house address and bill amount, and asking how it was calculated. There followed a three-way conversation as Saeen spoke to his inspector on the phone and to the lady sitting in front of him.

Saeen (to Mrs Chalak): 'Your mother-in-law died last year.'

Mrs Chalak: 'Ah ... yes' (slightly embarrassed as her lie is discovered).

Saeen (to Mrs Chalak): 'You live upstairs and downstairs you have a beauty parlour.'

Mrs Chalak: 'Oh, that is still under construction ...'

Saeen (to inspector): 'Isn't that still under construction?'

Saeen (to Mrs Chalak): 'There is some finishing work going on, but it is functional isn't it?'

Satisfied, Saeen put down his cellphone and addressed Mrs Chalak.

Saeen:

Mrs Chalak:

'So how much rent do you get for the parlour?'

'It's not on rent; I am running it myself.'

Note that the property tax payable would be considerably higher if the premises in question were, first, being used for commercial purposes and, second, rented out by the owner.

Saeen did not seem too convinced with Mrs Chalak's answer, but went on to make some calculations on the back of her bill. He kept calculating aloud so that Mrs Chalak could hear what he was doing and object if she did not agree with something. He kept flipping the bill to see the size of the plot and of the upper and lower stories of the building. He then applied the relevant rates and came up with a final assessment figure, which he underlined twice. He flipped the bill one last time and read off his figure, which was the same as that on the bill Mrs Chalak had brought with her. Saeen then explained the classifications he had used: 'self-occupied residential' for the upstairs floor of the building in which Mrs Chalak lived and 'self-commercial' for the beauty parlour on the ground floor. He had treated the car porch area on the ground floor as being in self-residential use and not commercial use, in exactly the same way as his inspector had when preparing the original bill. Saeen told Mrs Chalak that under the law he was to presume that any property not occupied by the owner is on rent. However he was taking a lenient view in her case. He advised her to get the property transferred in the name of the heir or heirs of her deceased mother-in-law, as this was required under the law. Mrs Chalak did not have anything further to say, but still did not seem very happy with her bill. She went away without saying anything about paying, and Saeen did not ask. 
Saeen then turned to me and explained that the increase in the bill was because the property no longer qualified for the reduction granted to widows. He remarked that Mrs Chalak would pay up once that information had sunk in. Saeen did not seem to resent the way in which she had tried to hide the truth about the death of her mother-in-law, the commercial use of the downstairs section as a beauty parlour, or the fact that it was likely rented out. Indeed he had given her the benefit of doubt on the latter point. Had he classified the downstairs as rented commercial premises, the tax bill for that part of the property would have increased fivefold. He explained that he had been lenient because he preferred to make a lower assessment and have her pay up, rather than assess her strictly and risk non-payment. He added that "even a rupee more in assessment than the "fair" assessment in the mind of the assessee raises the risk of non-payment multiple times'. That was a lesson he had learned in a quarter century of assessing and collecting property tax.

\section{Field-level administration: the underlying}

\section{system}

This routine interaction over Mrs Chalak's bill gives some clues about some important dimensions of field-level property tax assessment and collection processes in Pakistan.

First, circle-level property tax staff enjoy wide discretion in making assessments. Valuations are made for blocks of adjacent properties, not individual premises. All properties in a block are assigned to a category between A and G, according to an estimate of rentability that is based largely on the extent of infrastructure and service provision in the area. The taxes payable on any individual property within a block are then dependent on whether or not it is deemed to be used for commercial or residential purposes, whether it is owner-occupied or rented out, or whether the owners or occupants merit reductions because they are, for example, widows or retired public servants. Formally, the ETO is the assessing authority. $\mathrm{He}$ - and all are male - has the authority to change the basic rating value of a block of properties, a single property that is uniquely situated, or buildings in multiple (both residential and commercial) usage. He can reassign it from category $A$ to $B, C$ to $D$, etc. However standard procedures require the assessing authority to check only a limited proportion of valuations. Given the incompleteness of property registration systems and residence records, the complexities of joint family property rights, and the informality of most rental arrangements, circle staff enjoy enormous discretion. In most cases they, rather than the ETO, are the effective assessing authority. They also prepare and deliver the bills, and visit taxpayers repeatedly to follow up on payment until they receive or are shown the bank receipt as evidence that payment has been made. ${ }^{10}$ The billing process is itself complex. Bills are initially prepared on the assumption that they will be paid within the first three months of the financial year, and will therefore be eligible for a 5 per cent rebate. Should they not be paid in this time new bills are prepared. Duplicate bills are anyway delivered regularly as reminders. All these bills are prepared by hand. No duplicates are kept in the office.

Second, field staff do not generally use their discretion in ways that generate widespread resentment. Indeed, as the case above illustrates, they tend to make an effort to keep their taxpayers content, even at the cost of foregoing some revenue. ${ }^{11}$ This reflects the interaction

\footnotetext{
10 Property tax bills are issued in triplicate and copies have to be deposited in branches of National Bank under a designated treasury account. One copy is returned to the taxpayer, stamped as received by the bank. Two are sent to the district accounts office. One of the copies is collected by Excise and Taxation Department staff. They make an entry of payment in the district/region's central daily cash register. The copy is then sent down through the office of an ETO to the concerned circle inspector. He attaches the receipt to the page in his register that has details of the property.

11 When the property tax bill is generated it is supposed to reflect the tax assessment shown in Property Tax Register 8. However no copy of the actual bill is retained in the office; there is no universal numbering system for them; and in most
} 
of several features of the property tax system examined elsewhere in this paper: the ability of field-level staff to fend off pressure from above to increase collection; the danger of providing opportunities for local politicians to intervene on the side of taxpayers; and the potential cost of disrupting a set of arrangements that provide collectors with reliable revenue streams and most taxpayers with very low revenue demands.

Third, circle staff have a deep knowledge of virtually all properties within their jurisdiction, including both those that are registered - on average about 1,100 per staff member - and those that for one reason or another have not been registered and therefore escape payment. They maintain a written register of all property, which contains basic information on assessments, payments and arrears. But their personal knowledge is more extensive. The constable in particular is constantly out on the streets and haunts the local bazaars. He again, all are male - is known locally as a tax officer and is referred to by an honorific Chaudhri Sahib, Malik Sahib, Mian Sahib, Khan Sahib, Shah Sahib, and so on - according to his caste or lineage. Although circle staff have official uniforms that are similar to police uniforms, they do not normally wear them. The constable knows what is going on in the area, both generally and especially with respect to property. He has close contacts with local real estate dealers. Typically the constable serves his whole career of twenty to thirty years in one circle. He may see a house being constructed and therefore knows who owns it; what the owner does for a living; when it is initially occupied and hence becomes liable for property tax; whether it is owner-occupied or rented out; and whether it is being used for residential or commercial purposes. He also makes it his business to assess the political and social connections of the owner, and thus her/his negotiating power. When telephoned by his ETO, the inspector for the circle in which Mrs Chalak resided immediately recognised her property and knew the relevant recent history: the death of her mother-in-law and the progress in converting the ground floor into a beauty parlour. He had put an end to the widow's deduction on the property without waiting for Mrs Chalak to record formally the change in ownership of the property with the Board of Revenue. This was typical of the interactions observed by the first author in the four different ETO offices in which he did research.

Fourth, this valuable unwritten information is monopolised by the permanent circle staff, and not even shared with office assistants that they typically hire unofficially and privately to do clerical work. ${ }^{12}$ These unofficial assistants are young graduates with good numeracy skills. They are willing to work long hours for a relatively low monthly salary and an occasional 'bonus'. Their main motivation is the chance of being hired permanently if and when formal recruitment takes place. Only then will they begin to share in the rich information about the real property tax base and in the informal income associated with it. ${ }^{13}$ As temporary and informal assistants, they are never taken onto the street. As one of them expressed it, they have to run out of the building if there is an inspection visit by the director general or some other senior officer.

cases 'official' office stationery is purchased privately by circle staff. This creates scope for staff to produce fake, exaggerated bills, which could be used to extort money on the understanding that a new, lower bill will then be issued. This practice seems rare, apparently because it is likely to generate complaints from taxpayers to higher authorities. Similarly, tax staff have the legal authority to fine an assessee for non-payment up to the amount outstanding. However this is almost never done.

12 The work of an inspector's office includes maintaining a number of registers, issuing tax demand notices, recording payments and issuing reminders. As mentioned above, property tax staff are also responsible for collection of various other levies. All this is done manually. The work is routine but large in volume.

13 Retired circle staff are never rehired into the Excise and Taxation Department. They would have the knowledge to cut into the informal income of the other staff. By contrast in the Board of Revenue, which collects registration fees on changes on property ownership (among some other levies), the equivalent officers, known locally as Patwaris, are sometimes rehired informally after retirement to do routine work. In this case the main source of informal earnings is the signature of the official incumbent Patwari on property transfer documents. Informal employees cannot substitute and do not put this source of income under threat. 
Fifth, although field-level staff are required to maintain extensive handwritten records, these do not contain much of the deep knowledge they have of their tax base. Consequently that knowledge is not accessible to their supervisors: the regional directors and the provincial Director General of Excise and Taxation. The main official records - the assessments of individual properties - exist only in handwritten ledgers that are maintained and controlled by circle staff. They are not even routinely accessible to the ETO. But those formal records may be out of date, and more current information maintained in the heads of circle staff or in the private records that they sometimes maintain. The written records available in circle and rating area offices include information on amounts owed, payments and outstanding arrears. But the only financial information available to regional directors and above relates to total annual assessment and monthly collections within each circle. ${ }^{14}$ The collection totals given to regional directors are divided into current collection and collection of arrears. There are however no authentic cross-checked figures on the total amount of billing done in a particular year or on cumulative arrears. Senior officers do not know the extent to which annual collections reflect any increase or decrease in arrears owed. ${ }^{15}$ Those arrears can be large. As we explain further in Section 7, this information bottleneck is a significant element in the property tax system.

Sixth, the frequency of personal interactions between taxpayers and collectors is high relative to the monetary value of the transactions between them. The typical annual individual property tax assessment in Pakistan is equivalent to around US\$20. To collect that money the tax constable might meet the householder several times in a year, one year after another. There is little scope for effectively and efficiently monitoring these interactions from above.

Seventh, there is a substantial informal economy associated with property tax collection. On the basis of conversations with staff of six circles, the first author calculated that the average circle needed to raise about Rs.35,000 (US\$350) per month to meet those operational costs not provided for in the official budget: notably informal office assistants, office stationery and fuel and other operating costs for motorcycles and other vehicles that staff use. ${ }^{16}$ This kind of 'living off the land' is not unusual in the Pakistani public service. Senior officials justify providing inadequate operational budgets to tax offices with the argument that field staff anyway make a lot of money. This is less true of offices dealing with property tax than of other offices within the Excise and Taxation Department. Positions in offices collecting excise duties on liquor and motor vehicle taxes are more lucrative and more eagerly sought. However, property tax field staff certainly supplement their salaries significantly with informal earnings. In investigating this, the first author focused more on the proportional division of these informal earnings than on absolute amounts. There were some variations from office to office, and cases of individual officers who did not participate at all. But the phenomenon is broadly systemic. It is very difficult for individuals to decline to participate and have a satisfactory relationship with co-workers. It would also impinge on their ability to run their circles effectively. We were told that on average about 60-70 per cent of informal earnings were retained at circle level, with the inspector taking more than half and the constable and the clerk sharing the remainder. The other 30-40 per cent travels upwards. The great bulk of it stays in the office of the ETO (and the assistant ETO). We have no clear information on

14 The monthly collection figures are collated from information on bills paid that each regional director receives from the District Accounts Office. These figures in turn derive from the National Bank, where property owners are required to pay their bills. On payment taxpayers receive one of three copies of the tax demand with 'paid' stamped on it.

15 Until a few years ago there was a practice of having figures on arrears and current collections reported separately, with separate targets for each. However the information on arrears became highly unreliable. Inspectors maintain a separate record of arrears at circle level, but there is no effective cross-check of these figures. That would require that the arrears records for each inspector be checked manually. These records typically cover a period of about five years, with information for each year on annual bills and whether cleared for each of about 2,500 to 3,000 properties. This data might be contained in eight to ten thick registers.

16 In 2012 the government for the first time provided all tax inspectors with official motorcycles. But there was no budget for fuel. 
how consistently any of that money travels up to the office of the regional director. The regional director anyway oversees other offices of the Excise and Taxation Department collecting the more lucrative excise and motor vehicle taxes. There is a perception that it is more appropriate (cleaner, more honest) and less risky for the regional director to focus his attention on these other offices than on property tax collection. In talking of informal earnings, staff may use the local term for corruption. But they do not see this as unusual or in any major sense wrong. The words of one officer summarise the general view: 'We are all corrupt. You will not find a single officer in the department who is honest ... it is just that some are more corrupt than others'.

Respondents insisted that ETOs do not become very wealthy even after a lifetime's work, and especially not through property tax collection. ${ }^{17}$ The fact that property tax collectors collude directly with taxpayers to share in the money that formally belongs to the public treasury provides a ready legitimation for informal earnings: 'the public saves Rs.90 and gives us only Rs.10, and then they call us corrupt?' The sense of entitlement to informal earnings is strong.

Eighth, while there is a great deal of cooperation among staff at circle level around informal activities, there is not total trust and openness but rather a degree of individual vigilance and mutual suspicion. If an inspector is not particularly active in cross-checking information by spending time in the street, the constable can make additional money for himself by not pooling all 'deals' with the rest of the circle staff. For example, he could keep a few newlyconstructed properties off the official record, or continue to record as owner-occupied properties that have been rented out. As an informant remarked: 'the constable always keeps one or two properties out of a hundred for himself ... if the inspector is old or not very vigilant the constable and the clerk might collude and start running a sideshow of their own'.

Ninth, collusion between tax collectors and property owners to reduce assessments is not the statistical norm. Because rented and commercial properties are assessed so relatively highly, it is here that collusive activities are concentrated. Some of the rented shops in a large shopping plaza may be recorded and assessed as owner-occupied. In a multi-storey plaza, one whole floor might not be assessed at all. Since there are different tax rates for property on main roads and off main roads, a corner property may be shown wholly off the main road and charged a lower tax rate. A property being used as an office with no signboards outside may be recorded as residential and charged accordingly.

\section{Supervisors' dilemmas: an office meeting}

While field research for this paper was taking place the office of secretary to the Punjab provincial Excise and Taxation Department was occupied by a particularly energetic individual with good political connections, who tried hard to increase property tax collection. He was not long in post, and his efforts had no long-term effects (Section 8). They were however useful for the purpose of this research, because the reaction to them helped highlight important features of the tax collection system.

There were perceptible differences between different cities and towns in the way staff dressed and the private vehicles they drove. These corresponded with accounts of the varying potential for informal earnings. Some subordinate staff in smaller towns reported additional sources of income, like farming or small business. Only a handful of officers have made a lot of money and brought a bad name to the Excise and Taxation Department. But these were not in the property tax wing. They were mostly the 'blue-eyed' favourites of their superiors who remained for long periods in highly lucrative postings like Rawalpindi, which is the largest excise earner because a large brewery is located there. 
We begin with one of the regular monthly meetings where the secretary was quizzing the nine regional directors on progress in meeting their monthly tax collection targets. ${ }^{18}$ Note first that discussion was focused on two statistics for each regional directorate: the monthly collection level in the current year, and the equivalent figure for the previous year. As we explained above, the directors knew how much each circle had collected, but did not in practice know how much of the total collected constituted arrears, what were the accumulated arrears, or what was the overall property tax potential. The secretary believed it was possible to increase collection in the region for which Nikama was director, and gave him a higher target. Nikama refused to accept the revised target, claiming that it was unachievable. The secretary then asked another regional director, Kamu, whether he could do the job if transferred to Nikama's region. Kamu was willing to try if the target was reduced a little. Nikama was then given an opportunity to commit to achieving this slightly lower target. He declined. The secretary had little choice but to replace Nikama with Kamu. He asked Nikama to report to headquarters for further orders.

The outcome of this meeting was quite consequential for the two regional directors. For Kamu this was an opportunity. He was being transferred to a region that was more urbanised than his present posting and accordingly had more revenue potential, formally and informally. If he were to do well there, his next posting could be one of the three plum regional directorships in Lahore, the provincial capital. For Nikama this was a career setback. He had fallen out of favour with the secretary, and could not expect to get a decent posting as long as this secretary was in position. The two became involved in a complex conflict in which departmental disciplinary procedures, the courts, planted newspaper stories and political connections were all invoked. The secretary prevailed while he remained in office, but actually left the post after about a year.

\section{Supervisors' dilemmas: information asymmetry}

At first sight it seems surprising that senior public servants would become involved in intense conflict over an issue with such apparently low stakes. The potential additional revenue that was in dispute was trivial in the context of aggregate provincial tax collection, and even more trivial in the context of the provincial budget. We have less reason to be surprised when we look carefully at the context.

Senior departmental staff are highly present-oriented, focusing on monthly or annual collection targets from positions that they are unlikely to be occupying in two years time. From their perspective it is this year's target that matters, for that is a major indicator on which their performance will be judged. From 2010 to 2014 the average tenure of secretary and director general of the department was less than a year. Regional directors tend to be in post for a few years at most. However taxes are actually collected by field staff, who have very different career perspectives and interests. They expect to be in the same job or office for long periods of time, possibly throughout their careers. They are concerned about how their behaviour today might affect their capacity to work and earn in the future, especially as it might impact on their relationships with taxpayers and local politicians. Field staff are rarely moved out of their circles or districts, except as punishment in instances of serious or repeated complaints.

In fact senior staff have few disciplinary or other instruments available to change significantly the normal work practices and performance of their subordinates. At best they can

18 We did not attend this meeting, but received a detailed account from one of the participants. 
discourage blatant, visible misbehaviour. The Excise and Tax Department has a monitoring wing to investigate allegations of misbehaviour. The monitoring wing is however small, with staff only at the provincial level. If the monitoring wing or a senior officer on inspection unearths irregularities, the perpetrators can offer plausible excuses: they do not properly understand the rules; they are understaffed and too busy to check on everything; or the property was put to a different use only recently. If disciplinary action is initiated and charges proven, staff normally emerge with minor penalties that generally do not affect their jobs. While going through records of some of these disciplinary proceedings, the first author found that often the loss to the public exchequer was reported as having been made good through payment from the assesse - the taxpayer. Those restitutions were in turn cited as mitigating circumstances and a reason for the inquiry officers - who are appointed from within the Tax and Excise Department - to recommend leniency. No departmental staff, including those of the Human Resources Wing in the director general's office, could remember anyone being dismissed from service for under-assessing property. ${ }^{19}$

Even if they had more potent disciplinary tools, it would be difficult for senior staff to use them to motivate field staff to increase collection because they lack detailed information on their subordinates' work performance. They know collection totals by circle. They do not know how much of the money collected in any period represents current dues or arrears, the size of accumulated arrears or the actual taxable base. As we explain in the next section, control of information on arrears is a powerful strategic tool in the hands of field staff.

The only procedure available to senior staff to set collection targets for rating areas and circles is cash incrementalism: more money should be collected than last year. But how much more? The demands made by superiors and the responses to them are to a large degree shaped by instinct and intuition about how much slack might exist in different parts of the system. Everyone is to some degree operating on guesswork. Regional directors have no guaranteed means of achieving high targets. They will almost inevitably invoke their standard toolkit: intense regimes of inspection of subordinate offices, frequent cajoling of staff and, at the end of the year, a brief campaign to collect unpaid money (see Section 8). But the nearabsence of performance statistics means that it is hard for them to make an objective case to explain their failure to meet targets. It is sometimes rational for them to reject the targets that the secretary tries to set for them. It is equally rational for the secretary to encourage regional directors to compete for postings, often by giving them temporary postings ('acting charge') until they have proved their worth. The secretary has few other means of discovering where the additional collectable revenue lies. In particular, he has no information on how much potential revenue is sitting as uncollected arrears in each circle and rating area.

\section{Arrears}

A regional director told the first author how he once summoned a circle inspector to ask about the extent of cumulative arrears. The inspector reported that they amounted to about Rs.20 million (US\$200,000). When asked to bring all his registers to the regional office for inspection, the inspector revised that figure to Rs.40 million. By the time he arrived with the registers, his estimate was Rs.50 million. The director guessed that, had he taken the time to go through the registers, the real figure might have been double that. But he did not have the time. For the written information on arrears exists only - and at best - in the original registers, where it is recorded property by property. According to departmental regulations,

19 The Provincial Audit Department is responsible for external audit of the offices of the Tax and Excise Department. However this audit deals only with the internal consistency of office records. It involves no checking of the accuracy of property tax assessments. Further, several informants reported that passable audit reports are routinely exchanged for informal payments. 
inspectors should maintain separate registers that list out all properties in arrears along with sums outstanding. However these are badly maintained and rarely used.

It seems certain that property tax arrears are large relative to annual collections. The Excise and Taxation Department has no aggregate figures. Estimates given to us in different localities ranged from 50 per cent to 400 per cent of the annual tax demand.

\section{Arrears: the strategic use of information}

Accumulated arrears are not simply the result of the inability or unwillingness of circle staff to persuade property owners to pay up on time. They also reflect the fact that circle staff sometimes actively encourage property owners to accumulate arrears. Why would they do that? There seem to be several interacting reasons:

- One is that this gives field staff some leverage over the taxpayer concerned. The law gives revenue staff considerable authority to deal with property taxpayers in arrears. Under the Land Revenue Act they can institute legal proceedings for the recovery of outstanding government dues and, without court permission, seal immoveable property to prevent access by the owner, impound it, attach the rent of the property or even arrest the owner. These powers are rarely used, but field staff seem to find it useful to have at least some of their clients in a position where, in principle, such actions might be taken.

- More significant is the scope for staff and property owners to collude to accumulate large arrears on a property given out on rent. After some years staff can orchestrate an appeal by the owner on the grounds that the property had been self-occupied the whole time and that he was, for example, living abroad. The appellant authority in such cases is the regional director. His decision depends mainly on information provided by his field staff.

- There is in addition a more collective incentive for lower-level staff to encourage the accumulation of arrears. It helps them buffer demands from above. The kinds of interaction at the level of regional director discussed in Section 4 might at any moment generate a blitz of inspections and urging from superiors to ramp up collection. Field staff simultaneously cooperate in such campaigns and tacitly resist (Section 8). When under intense pressure it makes sense to yield a little more revenue. This could come from the informal earnings of the field staff. It could come from taxpayers, at the risk of upsetting them, and local politicians, by reneging on too many collusive assessment deals. A buffer of uncollected arrears provides a very useful alternative or supplement. It is relatively easy to press for payment of arrears when in real need of money, and allow arrears to accumulate again once pressure is relaxed. Because senior staff have little information on arrears, especially on accumulated arrears, it is very difficult for them to forestall this kind of response.

\section{Campaigning for collection}

Toward the end of most financial years staff of the Excise and Taxation Department engage in intensive collection campaigns to try to meet their target. This campaigning was particularly aggressive while the first author was doing field research in the financial year 2011/12. The secretary to the department mentioned in Section 4 was attempting to establish new records, and had sufficient political support to trespass beyond the normal boundaries. The first author witnessed this campaign in three different regions.

The following were the more visible components of the campaign: 
- Rather than travelling around individually in civilian clothing, circle staff went out in groups, generally in vehicles, wearing their official police-like uniforms that otherwise rarely saw the light of day, under the leadership of ETOs and regional directors.

- To encourage defaulters to pay, their properties were sealed. This did not make them completely inaccessible or unusable. It typically involved placing a lock on the front gate so that vehicles were unable to exit or enter, or access for people was inconvenient.

- Reports on collection were submitted frequently to superiors, and progress meetings held in offices every morning.

Like all campaigns, but with greater intensity, this one generated energetic and anxious responses from taxpayers, both individually and collectively, and sometimes from politicians representing them. This was most visible in the large number of people who flooded into the tax offices to pay, protest or explain. Compared to normal circumstances, the character of the property tax collection system seemed to change radically. The campaign was effective in the sense that total collection during the final quarter of that year $(2011 / 12)$ was considerably higher than in the previous year. The annual total also increased, although less markedly. But during the next year, after the energetic secretary had moved on, total annual collection increased only at the normal rate in cash terms, while the collection during the campaigning final quarter fell significantly compared to the previous year. In the longer-term perspective, intensive campaigning seems to have changed nothing. These campaigns have become institutionalised. All the main actors know broadly what to expect, and how to behave.

To some extent these campaigns generate a genuine sense of enthusiasm, mission and camaraderie among the field staff - and a degree of solidarity between them and senior staff. But field staff know that the support they are receiving from their superiors is only temporary. Once that recedes their relationship with - and need to accommodate - taxpayers and local politicians again has priority. So the appearance of strict enforcement is tempered by informal compromise. The properties of some defaulters are sealed with locks - but generally only to make them inaccessible to vehicles without interfering with their daily use. Although contrary to the law, properties may be unsealed if the owners pay only part of the arrears due. And, since a large number of defaulters are created through tolerating or encouraging arrears, field staff have considerable discretion about which defaulters to pursue.

Especially during enforcement campaigns, while they are in the field senior staff can use evidence or suspicion of misbehaviour on the part of their subordinate staff to squeeze a little more tax from them. For example, in one of the morning meetings a regional director asked an inspector to bring his arrears register. The register was actually a private notebook. The director showed the first author the long list of arrears, spread over many pages, and then mentioned that this particular inspector had won the highest cash award in the province for the last quarter under an experimental tax collectors incentive scheme (see Section 9). He turned to the inspector and said, 'You don't deserve a bonus that big, just look at your arrears. I should confiscate your award and buy office furniture with it'. He then went on to mark some of the larger amounts with a highlighter and numbered them, giving the inspector a week to show progress on the highlighted cases under the threat of a posting to a part of Punjab where he would certainly not be able to earn a bonus. The director was not interested in the details of arrears, provided he could use the list to raise some more revenue. No less than his field staff he was using informal practices - and tolerating the informal practices of his subordinates - while apparently engaged in a campaign to enforce formal procedures. 


\section{Concluding comments}

The current system for collecting property tax in the Punjab is pre-Weberian: discretion takes precedence over the use of standard rules and procedures; personal relationships between the taxpayer and tax collector greatly affect outcomes; the formal authority relationships are not backed by reliable disciplinary procedures and may be considerably influenced by relationships outside the organisation, notably with politicians; at the local level some staff and operating costs are covered by illegal earnings from collusion between tax collectors and taxpayers; and lower-level staff have to a large degree established exclusive control over the information that senior staff would need to monitor and measure staff and system performance effectively. In part because of this local-level 'information grab', there are significant elements of tax farming in the system. Especially at director level, the authority to collect property tax is to some extent assigned competitively, with bidders using a range of private and experiential knowledge to estimate potential collection levels in different locations. These regressive characteristics in large part stem from the fact that the system is based on physical verification, not accounts (see Introduction). Similar systems for raising revenue, especially for local governments and in customs, are widespread in low-income parts of the world. ${ }^{20}$

But property tax collection in the Punjab does not have to be like this. Digital technologies have greatly improved the prospect of assessing and collecting urban property taxes more reliably, efficiently and transparently. Geographic information systems make it easier and cheaper to identify - and to some extent to classify - properties liable to taxation. Bill management can be automated. Management information systems can be used to analyse system performance in many dimensions. Property tax information can be cross-checked with relevant information from, for example, household utility bills, the census, or taxes on the legal transfer of property. From the technological perspective it is easy to imagine a property tax organisation in the Punjab that would be much more Weberian - and would generate much more revenue - than the current system. Indeed, computerising property tax systems in places like Pakistan is widely seen as the obvious option. A number of aid and development organisations have financed projects intended to help bring this about in recent years. But these projects have made little progress. How could our analysis of the ways in which the Excise and Taxation Department currently goes about its work inform future reform initiatives? ${ }^{21}$

References to the evidence for our first conclusion is scattered in the text above, but the point so far has remained implicit: it is far from clear that politicians and governments at various levels in Pakistan actually place much value on a more effective property tax system. If they did, would they create such a complex and unbalanced system for dividing the responsibility for collecting property tax and the revenue collected between three different tiers of subnational government (Section 1)? Would they give such low operational budgets to the field offices of the Excise and Taxation Department that they are required to fund some operational costs informally (Section 3)? Would they allow disciplinary and financial control procedures in the department - that were to some extent respected in earlier decades - to atrophy (Sections 6 to 8)? Would they multiply the number of competing levies on transfer of legal property rights, rather than trying to consolidate (Section 1)?

\footnotetext{
20 We have evidence from a range of other countries of similar sets of informal practices in tax collection, including in particular the informal employment of supplementary staff; complex patterns of illicit collaboration between tax collectors, taxpayers and various kinds of intermediaries; and the institutionalised redistribution of illegal rents within the revenue organisation and beyond (Bilangna and Djeuwo 2013; Blundo 2006; Cuvelier and Mumbunda 2013; Fjeldstad and Therkildsen 2008; Titeca 2009; Titeca and Kimanuka 2012).

21 For other analyses of reform options for property tax in Pakistan, see Nabi and Shaikh (2011) and World Bank (2006).
} 
Rather than claim that Pakistani governments have explicitly chosen to create or permit a weak apparatus to collect property tax, it may be historically and analytically more accurate to suggest that they, along with various other actors, have allowed the system to sink to a low-level equilibrium - of weak administration, low revenue, rent-taking, low legitimacy, low operating budgets - because other policy objectives have been given priority. Likely the main tangible motive for national governments has been to keep subnational administrations relatively weak and divided among themselves. The Punjab Provincial Government seems to take a similar attitude to lower-level jurisdictions within the province. ${ }^{22}$ Less tangibly, responsibility for the property taxation system has become so divided - and the revenue yield for any one actor so relatively low - that no demand or coalition for reform has emerged. It is probably true that politicians and political elites have been wary of property taxes for fear that they would themselves face large tax bills. But that cannot be a complete explanation: the same people have overseen the multiplication of taxes on legal property transfers. These are not property taxes in the colloquial sense in which we use the term here. But they are taxes on property ownership.

Our first conclusion for property tax reformers is then the simple warning that the political support at government level that such a complex reform would require might not be forthcoming.

Our second and third conclusions can also be phrased as simple warnings. Attempts to change the system through tightening bureaucratic control, and efforts to exert discipline and jack up collection targets, are unlikely to be successful. The same applies to attempts to motivate field staff to work better by paying them cash bonuses for increasing collection. Given the high degree to which staff pursue informal practices, collect illicit revenue and transfer some of that money between offices in an institutionalised fashion, it is hard to see how collection bonuses could motivate staff in a cost-effective way, or bring about systemic reform. ${ }^{23}$

Our final and more positive conclusion is the most diffuse. The field staff of the Excise and Taxation Department have established a considerable degree of de facto control over activities of the department and the options available to its senior managers. Field staff have done this especially by establishing a high degree of local control over the information that would be needed to be centralised, aggregated and analysed if senior staff were to be able actively to manage and improve the property tax system. Field staff are in large part motivated by the desire to protect their informal earnings. But those informal earnings are not large. From the perspective of reforming this system, it would be a mistake to emphasise corruption or prioritise ways of reducing it. There is in principle considerable scope for reform. One can imagine a property tax system, based on increasing use of electronic technologies, that would encompass more properties, yield more revenue, reduce collection costs, ease the taxpaying experience for at least some taxpayers, and still provide employment for some existing field staff. It is hard to imagine bringing this about without having a good understanding of how the present system operates. Any sustainable strategic change will have to be negotiated more or less directly with existing staff, offering them assurances in return for their cooperation.

These points are developed in the first author's forthcoming doctoral thesis.

An experimental bonus scheme was initiated in a few areas in 2009/10. It was originally motivated by an expectation that bonuses would be effective. The researchers have, however, discovered that, although cash bonuses did increase reported collection, they also increased the level of extraction from taxpayers by collectors: 'The results are consistent with a collusive setting in which performance pay increases collector's bargaining power over taxpayers, who either have to pay higher bribes to avoid being reassessed, or pay substantially higher taxes if collusion breaks down' (Khan et al. 2014 Abstract). 


\section{References}

Aberbach, J. and Christensen, T. (2007) 'The Challenges of Modernizing Tax Administration', Public Policy and Administration 22(2): 155-182, doi: 10.1177/0952076707071501

Adams, C. (1998) Those Dirty Rotten Taxes. The Tax Revolts that Built America, New York and London: The Free Press

Awasthi, R. and Bayraktar, N. (2014) Can Tax Simplification Help Lower Tax Corruption?, Policy Research Working Paper 6988, Washington DC: World Bank

Bahl, R., Martinez-Vasquez, J. and Youngman, J. (eds) (2008) Making the PropertyTax Work. Experiences in Developing and Transitional Countries, Cambridge MA: Lincoln Institute of Land Policy

Bergman, M. (2003) 'Tax Reforms and Tax Compliance: The Divergent Paths of Chile and Argentina', Journal of Latin American Studies 35(3): 593-624

Bilangna, S. and Djeuwo, M. (2013) 'The Figures Culture in Cameroon Customs', in T. Cantens, R. Ireland and G. Raballand (eds), Reform by Numbers. Measurement Applied to Customs and Tax Administrations in Developing Countries, Washington DC: World Bank

Bird, R. (2004) 'Administrative Dimensions of Tax Reform', Asia and Pacific Tax Bulletin 10(3): $134-150$

and Slack, E. (2006) Taxing Land and Property in Emerging Economies: Raising Revenue ... and More?, International Tax Program Paper 0605, Toronto: University of Toronto

- - (eds) (2004) International Handbook on Land and Property Taxation, Cheltenham: Edward Elgar

— and Zolt, E. (2008) 'Technology and Taxation in Developing Countries: From Hand to Mouse', National Tax Journal 61(4): 791-821

Blundo, G. (2006) 'Dealing with the Local State: The Informal Privatization of Street-Level Bureaucracies in Senegal', Development and Change 37(4): 799-819

Bräutigam, D. (2008) 'Introduction: Taxation and State Building in Developing Countries', in D. Bräutigam, O-H. Fjeldstad and M. Moore (eds), Taxation and State Building in Developing Countries. Capacity and Consent, Cambridge and New York: Cambridge University Press

Butcher, J. and Dick, H. (eds) (1993) The Rise and Fall of Revenue Farming. Business Elites and the Emergence of the Modern State in Southeast Asia, New York: St. Martin's Press

Cantens, T., Raballand, G. and Bilanga, S. (2010) 'Reforming Customs by Measuring Performance: A Cameroon Case Study', World Customs Journal 4(2): 55-73 
Connolly, K. and Bell, M. (2009) Area-Based Property Tax Systems: Current Practice and Equity Concerns, Lincoln Institute of Land Policy Working Paper WP09KC1, Cambridge MA: LILP

Cuvelier, J. and Mumbunda, P. (2013) 'Réforme Douanière Néolibérale, Fragilité Etatique et Pluralisme Normatif. Le Cas du Guichet Unique à Kasumbalesa', Politique Africaine 129: 93-112

Daunton, M. (2001) Trusting Leviathan. The Politics of Taxation in Britain 1799-1914, Cambridge: Cambridge University Press

Fjeldstad, O-H. and Therkildsen, O. (2008) 'Mass Taxation and State-Society Relations in East Africa', in D. Bräutigam, O-H. Fjeldstad and M. Moore (eds), Taxation and StateBuilding in Developing Countries: Capacity and Consent, Cambridge: Cambridge University Press

Gardner, L. (2012) Taxing Colonial Africa: the Political Economy of British Imperialism, Oxford: Oxford University Press, Oxford Scholarship Online

Hale, D. (1985) 'The Evolution of the Property Tax: A Study of the Relation between Public Finance and Political Theory', Journal of Politics 47(2): 382-404

IMF (2011) Revenue Mobilisation in Developing Countries, Washington DC: International Monetary Fund

Jibao, S. and Prichard, W. (2013) Rebuilding Local Government Finance After Conflict: The Political Economy of Property Tax Reform in Post-Conflict Sierra Leone, ICTD Working Paper 12, Brighton: International Centre for Tax and Development

Kelly, R. (2013) 'Property Tax Collection and Enforcement', in W. McCluskey, G. Cornia and L. Walters (eds), A Primer on Property Tax: Administration and Policy, Hoboken NJ: Wiley

Khan, A., Khwaja, A. and Olken, B. (2014) Tax Farming Redux. Experimental Evidence on Performance Pay for Tax Collectors, IGC Working Paper, London: International Growth Centre

Kidd, M. ( 2010) Revenue Administration: Functionally Organized Tax Administration, Technical Notes and Manuals, Washington DC: International Monetary Fund, Fiscal Affairs Department

Kloeden, D. (2011) Revenue Administration Reforms in Anglophone Africa Since the Early 1990s, IMF Working Paper WP/11/162, Washington DC: International Monetary Fund

McCluskey, W., Cornia, G. and Walters, L. (eds) (2013) A Primer on Property Tax: Administration and Policy, Hoboken NJ: Wiley

Moore, M. (2014) 'Revenue Reform and Statebuilding in Anglophone Africa', World Development 60(8): 99-112, doi: <http://dx.doi.org/10.1016/j.worlddev.2014.03.020>

Nabi, I. and Shaikh, H. (2011) Reforming the Urban Property Tax in Pakistan's Punjab, Working Paper, Lahore: Development Policy Research Centre, Lahore University of Management Sciences 
National Institute of Urban Affairs (2010) Best Practices in Property Tax Reforms in India, Delhi: National Institute of Urban Affairs

Norregaard, J. (2013) Taxing Immovable Property. Revenue Potential and Implementation Challenges, IMF Working Paper WP/13/129, Washington DC: International Monetary Fund

Orton, M. (2005) 'Inequality and the Reform of a Regressive Local Tax: The Debate in the UK', Social Policy and Society 4(03): 251-258, doi:10.1017/S1474746405002393

Phillip, J. and Gary, C. (2003) 'Moral Hazard in Property Tax Administration: A Comparative Analysis of the Czech and Slovak Republics', Comparative Economic Studies, 45(1): 44

Rao, M. (2013) Property Tax System in India: Problems and Prospects of Reform, Delhi: National institute of Public Finance and Policy

Titeca, K. (2009) 'The 'Masai' and Miraa: Public Authority, Vigilance and Criminality in a Ugandan Border Town', Journal of Modern African Studies 47(2): 291-317

— with Kimanuka, C. (2012) Walking in the Dark: Informal Cross-border Trade in the Great Lakes Region, International Alert

Vázquez-Caro, J. and Bird, R. (2010) 'Benchmarking Tax Administrations in Developing Countries: A Systemic Approach', E Journal of Tax Research 9(1): 5-37

Webber, C. and Wildavsky, A. (1986) A History of Taxation and Expenditure in the Western World, New York: Simon Schuster

World Bank (2006) Property Taxes in the Punjab, Pakistan, Islamabad: World Bank, Infrastructure and Energy Department, South Asia Region

Zake, J. (2011) Customs Administration Reform and Modernization in Anglophone Africa Early 1990s to Mid-2010, IMF Working Paper WP/11/184, Washington DC: International Monetary Fund 


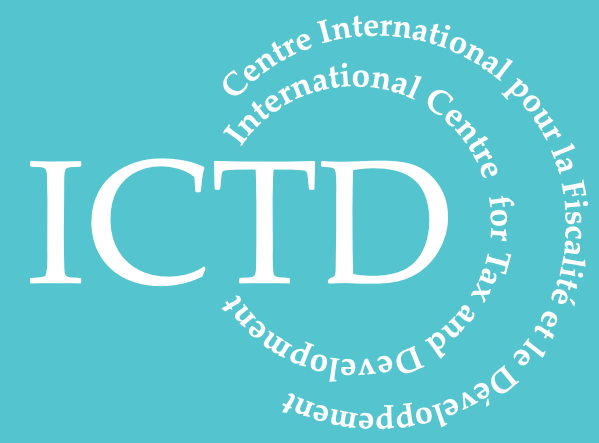

International Centre for Tax and Development at the Institute of Development Studies

Brighton BN1 9RE, UK

T: +44 (0) 1273606261

F: $+44(0) 1273621202$

E: info@ictd.ac

www.ictd.ac 